\title{
Model Pembelajaran SETS Berbantuan Media Audio Visual Terhadap Kompetensi Pengetahuan IPA
}

\author{
I Made Sudarmawan \\ Program Studi Pendidikan Guru Sekolah Dasar, Universitas Pendidikan Ganesha \\ sudarmawanmade364@gmail.com
}

Ida Bagus Gede Surya Abadi

Program Studi Pendidikan Guru Sekolah Dasar, Universitas Pendidikan Ganesha Idabagusgedesurya.abadi@undiksha.ac.id

Made Putra

Program Studi Pendidikan Guru Sekolah Dasar, Universitas Pendidikan Ganesha putra.made3112@gmail.com

\section{A R T I C L E I N F O \\ Article history: \\ 1 Juli 2020 Received in \\ revised form \\ 30 Agustus 2020 \\ Accepted 28 September 2020 \\ Available online \\ 30 September 2020

Kata Kunci:
SETS, Audio Visual,
Kompetensi Pengetahuan
IPA
Keywords:
SETS, Audo Visual, Science
Knowladge Competence

\begin{abstract}
AB S T R A K
Rendahnya kompetensi pengetahuan IPA siswa yang disebabkan oleh kurang optimalnya penggunaan model pembelajaran menyebabkan siswa sulit untuk memahami pembelajaran. Berkenaan dengan hal tersebut, penelitian ini bertujuan untuk menganalisis pengaruh yang signifikan model pembelajaran SETS Berbantuan Media Audio Visual terhadap kompetensi pengetahuan IPA kelas V SD. Penelitian ini merupakan penelitian eksperimen semu dengan desain Nonequivalent Control Group Design. Data yang diperoleh dianalisis dengan uji-t menggunakan rumus Polled Varians. Berdasarkan analisis diperoleh $t_{\text {hitung }}=3,154$ kemudian dibandingkan dengan nilai $t_{\text {tabel }}(2,000)$ pada taraf signifikansi $5 \%$ dan
\end{abstract} $\mathrm{dk}=60$ yaki. Dari perbandingan diperoleh karena $t_{\text {hitung }}>\mathrm{t}_{\text {tabel }}$ sehingga $\mathrm{H}_{\mathrm{o}}$ ditolak. Ini berarti terdapat perbedaan yang signifikan kompetensi pengetahuan IPA antara kelompok yang dibelajarkan menggunakan model pembelajaran SETS Berbantuan Media Audio Visual dengan kelompok yang dibelajarkan menggunakan pembelajaran konvensional pada siswa kelas V SD Tahun Ajaran 2019/2020.

\begin{abstract}
AB S T R A K
The low competence of students' science knowledge is caused by the less optimal use of the learning model which makes it difficult for students to understand learning. In this regard, this study aims to analyze the significant effect of the Audio Visual Media Assisted SETS learning model on the science knowledge competence of fifth grade elementary school students. This research is a quasi-experimental research design with Nonequivalent Control Group Design. The data obtained were analyzed by t-test using the Polled Variance formula. Based on the analysis obtained tcount $=3.154$ then compared with the value of ttable $(2,000)$ at the $5 \%$ significance level and $d k=60$ yaki. From the comparison obtained because tcount $>$ ttable so that Ho is rejected. This means that there is a significant difference in the competence of science knowledge between the groups that are taught using the Audio Visual Media Assisted SETS learning model and the groups that are taught using conventional learning in fifth grade elementary school students for the 2019/2020 academic year.
\end{abstract}




\section{PENDAHULUAN}

Pendidikan dapat menciptakan manusia yang berkualitas, serta mampu bersaing di era global seperti saat ini dan mampu menciptakan moral yang baik. Pendidikan terdiri dari beberapa komponen untuk mencapai itu semua, salah satunya kurikulum. Kurikulum memiliki peranan yang sangat penting dalam dunia pendidikan, kurikulum yang diterapkan saat ini adalah kurikulum 2013 dengan pendekatan saintifik (5M). Kurikulum 2013 bertujuan untuk menghasilkan individu yang beriman kreatif, produktif, inovatif dan afektif serta diharapkan bisa berkontribusi pada kehidupan berbangsa dan bernegara. Penerapan kurikulum 2013 pada tingkat sekolah dasar menggunakan tematik integratif, yaitu mengaitkan beberapa mata pelajaran ke dalam sebuah tema. Sebuah tema terdiri dari tiga atau empat subtema, dalam subtema tersebut terdiri dari enam pembelajaran. Mata pelajaran seperti Bahasa Indonesia, PKn, IPA, IPS, Penjaskes, dan SBdP dipadukan dalam kegiatan-kegiatan pembelajaran dalam suatu tema, sehingga siswa tidak menyadari sedang mempelajari mata pelajaran tertentu. Dengan demikian mereka dapat memahami suatu konsep dengan utuh bukan hanya sebagai pengetahuan tetapi juga dapat diterapkan melalui kegiatan-kegiatan dalam pembelajaran. Salah satu muatan materi yang terintegrasi dalam kurikulum 2013 adalah muatan materi IPA atau Ilmu Pengetahuan Alam (Nursa, 2015).

IPA mencakup semua objek dengan hukum-hukum yang pasti dan umum (Samatowa, 2016). IPA adalah usaha setiap individu untuk dapat memahami alam sekitar dengan cara melakukan penelitian, prosedur yang sesuai, penjelasan dan menarik kesimpulan (Susanto, 2013). Menurut penelitian yang dilakukan Rini (2017) IPA adalah ilmu pengetahuan yang didalamnya mempelajari tentang manusia dan lingkungannya. Dalam muatan materi IPA, siswa belajar dengan cara menemukan sebuah konsep atau fakta secara langsung di lapangan dengan cara-cara yang ilmiah namun tetap menyenangkan (Amelia, 2019). Konsep pembelajaran IPA di sekolah dasar mengaitkan antara hubungan manusia dengan alam sekitar yang dilaksanakan melalui proses ilmiah sebagai dasar memperoleh pengetahuan (Desy Anwar, 2020). Proses ilmiah dapat diperoleh melalui penyelidikan, penyusunan, dan penyajian gagasan sebagai langkah dalam mengerjakan, melakukan, dan memahami alam sekitar. Pembelajaran IPA yang dipelajari di sekolah dasar lebih menekankan pada konsep dasar untuk memperoleh pengetahuan, konsep, dan gagasan yang berkaitan dengan alam sekitar. IPA adalah ilmu yang mencakup aspek yang tidak dapat dipisahkan, yang pertama adalah produk, kedua yakni proses dan ketiga yaitu sikap (Ansori et al., 2020).

Proses IPA menciptakan pengetahuan yang merupakan produk IPA dan produk menjadi objek yang diteliti sehingga melewati tahapan maupun proses IPA serta mampu menghasilkan pengetahuan yang baru yaitu produk. Proses yang dilalui tersebut merupakan proses IPA. Cenderung bersikap yang melandasi sikap IPA merupakan perwujudan IPA sebagai sikap. Tujuan pembelajaran IPA tersebut dapat tercapai apabila dalam proses pembelajaran siswa selalu aktif memperoleh pengetahuannya sendiri melalui proses sains (Purwanto \& Aminah, 2020). Pembelajaran IPA yang dilaksanakan di sekolah dasar hendaknya melewati proses yang memberikan kesempatan siswa belajar secara nyata. Menurut teori Piaget, siswa sekolah dasar termasuk dalam fase operasional konkret sebab pada fase ini siswa dinilai telah mampu melakukan penalaran logis terhadap segala sesuatu yang bersifat konkret, tetapi siswa belum mampu melakukan penalaran untuk hal-hal yang bersifat abstrak (Mahdalena \& Sain, 2018). Oleh karena itu siswa perlu dibelajarkan secara nyata dalam kegiatan belajarnya. Namun kenyataannya, di sekolah dasar banyak siswa 
kesulitan saat pembelajaran IPA disebabkan karena mereka cenderung menghafal konsep atau teori saja. Kegiatan belajar yang berupa hafalan teori merupakan hal yang sulit bagi siswa sekolah dasar mengingat karakteristik siswa yang senang belajar secara nyata, bukan berupa pemahaman materi. Hal ini sejalan dengan pendapat Ardianti et al. (2019) menyatakan IPA selalu dianggap sebagai hal yang sulit bagi siswa karena memerlukan lebih banyak hafalan dan pemahaman teoretis dengan istilah-istilah yang sulit. Siswa belum sepenuhnya mampu menguasai materi pembelajaran sehingga menyebabkan siswa belum mampu untuk memperoleh nilai KKM yang ditentukan yaitu 75 .

Berdasarkan hasil observasi dan wawancara yang dilaksanakan pada kelas V dari tanggal 27 sampai 28 Oktober 2019 di seluruh SD Gugus IV Kuta Utara, didapatkan nilai kompetensi Penilaian Tengah Semester (PTS) IPA siswa masih ada yang belum mencapai nilai KKM. Dari 209 orang siswa sebanyak 140 atau $67 \%$ belum mencapai nilai KKM, sedangkan sisanya sudah mencapai nilai KKM, selain itu juga ditemukan permasalahan kurangnya minat siswa dalam mengikuti pembelajaran IPA, siswa cenderung merasa cepat bosan pada saat pembelajaran IPA. Padahal pembelajaran seharusnya dapat bermakna dimana siswa menghubungkan informasi atau materi pelajaran baru dengan konsep-konsep atau hal lainnya yang telah ada dalam struktur kognitifnya sehingga dapat diaplikasikan pada kehidupan sehari-hari siswa itu sendiri. Pembelajaran yang dilaksanakan pula cenderung berceramah saja. Kemampuan siswa dalam pembelajaran di kelas arahkan pada kegiatan menghafal saja. Kurangnya pengemasan pembelajaran dengan pemilihan model pembelajaran yang tepat juga menyebabkan siswa cenderung bermain dan tidak fokus dalam belajar. Sejalan dengan Sabardila et al. (2020) peranan guru berpengaruh dalam proses pembelajaran melalui pemilihan model pembelajaran yang tepat dengan materi yang diajarkan karena suatu model belum tentu cocok digunakan untuk setiap pokok bahasan yang berbeda. Hal tersebut berarti pemilihan model pembelajaran sangat berpengaruh terhadap suasana belajar di kelas karena akan berpengaruh pada kompetensi pengetahuan IPA siswa.

Permasalahan siswa kurang aktif dan cenderung bosan pada kegiatan belajar sehingga partisipasi siswa rendah yang juga ditemukan karena pembelajarannya hanya dilaksanakan sebatas menghafal dan terbatas pada buku saja juga menyebabkan siswa jenuh karena kurangnya sumber belajar yang menarik. Hal ini sejalan dengan Desstya (2018) yang menyatakan bahwa pertimbangan untuk membelajarkan IPA di SD adalah sumber belajar, yang dapat berupa buku, lingkungan sekitar, media, atau yang lain. Hal tersebut berarti sumber belajar tidak hanya terpaut pada buku saja. IPA sangat memberikan peluang bagi guru untuk menggunakan sesuatu yang ada di lingkungan sekitarnya agar lebih bisa memvisualkan konsep yang akan disampaikan. Tentu permasalahan yang terjadi dipengaruhi faktor penyebab yang datang dari dalam diri siswa dan mungkin pula faktor bukan dari diri siswa yaitu guru. Oleh karena itu pembelajaran yang menyenangkan, aktif serta menarik sangat diperlukan bagi siswa yang diciptakan oleh guru agar mampu mencapai tujuan pembelajaran yang telah ditentukan. Menurt Yamin \& Karmila (2020) IPA merupakan ilmu yang pembelajarannya menekankan pada pemberian pengalaman langsung untuk mengembangkan kompetensi agar menjelajahi dan memahami alam sekitar secara ilmiah serta mengingat siswa di sekolah dasar yang suka dibelajarkan dengan sistem berkelompok maka solusi yang tepat untuk membuat suasana belajar menarik serta mampu mendorong siswa belajar diperlukan solusi untuk suatu model pembelajaran yang inovatif. 
Mencermati permasalahan belajar yang diuraikan di atas, dalam penelitian ini diterapkan sebuah inovasi baru yaitu pendekatan dalam pembelajaran yang dapat mempengaruhi kompetensi pengetahuan IPA siswa sehingga proses pembelajaran IPA berjalan secara optimal. Beragam model pembelajaran yang bisa diterapkan diantaranya adalah model SETS. Pendekatan tersebut adalah model SETS (Science, Environment, Technology, and Society). SETS merupakan kepanjangan dari Science, Environment, Technology, and Society yang merupakan salah satu model pembelajaran yang dimana permasalahan yang memiliki komponen sains dan teknologi yang didalamnya terdapat konsep - konsep dipusatkan pada dunia nyata dan siswa diajak untuk memecahkan hal tersebut (Fatchan et al., 2014). lebih lanjut Wisudawati (2017) mengatakan bahwa model pembelajaran ini merupakan sebuah pembelajaran yang mengaitkan sains dengan hal yang berada disekitar kita seperti lingkungan, teknologi dan masyarakat. Dari pendapat tersebut dapat disimpulkan bahwa pembelajaran SETS adalah model pembelajaran yang selalu mengangkat permasalahan yang memiliki konsep - konsep dimana didalamnya terdiri dari unsur sains dan teknologi yang sedang berkembang disekitar kita seperti lingkungan, teknologi dan masyarakat.

Sintak model pembelajaran SETS adalah 1) Inisiasi, Guru mengangkat sebuah permasalahan sehari - hari yang masih hangat lalu siswa dituntut untuk memahami permasalahan tersebut, 2) Penetapan kompetensi sains, guru menentukan standar kompetensi dan kompetensi dasar yang berkaitan dengan permasalahan tersebut. Penetapan kompetensi ini dapat dilakukan sebelum kegiatan inisiasi, 3) Dekontekstualisasi, Siswa diajak untuk fokus pada pembelajaran konsep / prinsip-prinsip awal yang berkaitan dengan kompetensi sains dan meminta siswa untuk meninggalkan tentang masalah yang diangkat 4) Pembelajaran Konsep dan Prinsip Sains, guru melakukan pembelajaran konsep dan prinsip sains dan memastikan siswa agar benar-benar paham terhadap konsep tersebut 5) Penerapan, pada tahap ini, siswa menerapkan konsep dan prinsip sains yang telah diajarkan tadi pada permasalahan yang diangkat sebelumnya (tahap inisiasi), dan guru bertugas membimbing siswa. 6) Perangkuman, guru bersama siswa menyimpulkan mengenai pembelajaran yang telah dilakukan. Media pembelajaran dapat digunakan oleh guru untuk menyampaikan materi pembelajaran sehingga siswa mudah dalam menangkap serta memahami materi pembelajaran. Media pembelajaran juga menunjang proses belajar siswa lebih menarik dan menyenangkan. Media yang dapat digunakan untuk melengkapi model pembelajaran SETS adalah pemanfaatan media audio visual (Aprianingtyas \& Sumadi, 2016).

Media audio visual adalah media yang termasuk kedalam media yang mengandung unsur suara dan juga mengandug usnur gambar yang penggunaan medianya dengan rekaman video. Guru yang lebih banyak menggunakan metode ceramah dan tanya jawab selama kegiatan pembelajaran berlangsung. Kegiatan pembelajaran hanya berpusat pada guru. Selain itu, beberapa siswa kurang mampu mempergunakan lingkungan disekitarnya dengan baik untuk dipakai menjadi sumber belajar (Yuniastuti, 2015). Jika hal tersebut dibiarkan begitu saja, maka pembelajaran tentu tidak dapat berlangsung secara optimal. Berbagai faktor yang menyebabkan rendahnya kompetensi pengetahuan IPA siswa yaitu faktor internal dan faktor eksternal. Faktor internal merupakan faktor yang bersumber dari luar diri peserta didik yaitu keluarga, sekolah, dan masyarakat. Dalam kegiatan pembelajaran dikelas untuk menunjang kelancaran dalam penyampaian suatu materi, guru dapat memadukan model pembelajaran SETS dengan media pembelajaran (Subawa, 2018). 
Media pembelajaran merupakan suatu komponen pembelajaran yang memiliki kaitan erat dan memiliki peran penting dalam menunjang keberhasilan suatu pembelajaran. Media pembelajaran dapat digunakan oleh guru untuk menyampaikan materi pembelajaran sehingga siswa mudah dalam menangkap serta memahami materi pembelajaran (Irwandi, 2019). Media pembelajaran juga menunjang proses belajar siswa lebih menarik dan menyenangkan. Media yang dapat digunakan untuk melengkapi model SETS adalah audio Visual. Media merupakan alat yang membantu siswa untuk mampu memahami pembelajaran (Devi et al., 2019).

Pemanfaatan media menjadikan siswa yang pasif menjadi lebih mengeksplorasi pengetahuan di lingkungan sekolah sehingga materi yang didapat menjadi bermakna bagi siswa karena memberikan pengalaman langsung kepada siswa dalam belajarnya. Hal ini sejalan dengan pendapat Sary et al. (2020) bahwa SETS mampu membuat pembelajaran menjadi makin bermanfaat karena anak dihadapkan tepat pada situasi dan kondisi yang sebenarnya dan bersifat alami. Bermacam media pembelajaran dapat dipadukan atau digunakan dalam proses penyampaian materi pada kegiatan pembelajaran namun disesuaikan terhadap materi yang dijelaskan, salah satunya yaitu media pembelajaran audio visual. Sejalan dengan pendapat Laka (2017) menyatakan audio visual adalah media yang mampu menyajikan unsur suara (audio) serta gambar (visual) secara beriringan dalam mengkomunikasikan informasi. Audio visual dilihat dari arti kata audio dan visual berarti media yang dapat didengar sekaligus dilihat (Hayati \& Harianto, 2017). Menurut Asmara (2015) menegaskan audio visual merupakan media perantara yang melibatkan pandangan serta pendengar yang mampu membuat suasana pembelajaran menjadi menarik. Berdasarkan pemaparan diatas dapat dirangkum bahwa media audio visual adalah media perantara yang mengandung komponen suara dan gambar yang dapat dilihat dan didengarkan secara terpadu saat mengkomunikasikan informasi.

Model pembelajaran SETS berbantuan media audio visual yaitu sebuah model pembelajaran yang selalu mengangkat permasalahan yang memiliki konsep - konsep dimana didalamnya terdiri dari unsur sains dan teknologi yang sedang berkembang disekitar kita seperti lingkungan, teknologi dan masyarakat, yang dimana penyampain informasinya melalui media perantara yang mengandung komponen suara dan gambar yang dapat dilihat dan didengarkan secara terpadu saat mengkomunikasikan informasi (Ayu Wirati, 2014). Dengan menerapkan model pembelajaran SETS berbantuan media audio visual pembelajaran menjadi lebih efisien dan efektif sehingga mampu meningkatkan kompetensi pengetahuan IPA siswa (Fujiyanto et al., 2016). Kompetensi yaitu pengetahuan yang dimiliki oleh siswa dalam melaksanakan tugas dalam proses pembelajaran. Menurut Agung (2012) menyatakan bahwa kompetensi merupakan penguasaan suatu ilmu pengetahuan, bersikap, dan keterampilan sesuai dengan objek tertentu atau mata pelajaran yang sudah diajarkan. Sedangkan menurut Kosasih (2016) menyatakan bahwa kompetensi merupakan sesuatu yang sangat komplek karena ada banyak aspek yang harus diperhatikan didalamnya sehingga harus di pikirkan dangan matang. Salah satu aspek atau ranah itu ialah kompetensi pengetahuan dalam ranah kompetensi pengetahuan terdapat enam jenjang proses berpikir yaitu mengingat, memahami, menerapkan, menganalisis, mengevaluasi, dan mencipta. Keenam aspek ini biasanya digunakan untuk merumuskan tujuan pembelajaran yang dikenal dengan $\mathrm{C} 1$ sampai dengan $\mathrm{C} 6$. Tujuan penelitian ini adalah untuk mengetahui pengaruh yang signifikan model pembelajaran SETS berbantuan media 
audio visual terhadap kompetensi pengetahuan IPA siswa kelas V SD Gugus IV Kuta Utara Tahun Ajaran 2019/2020.

\section{METODE PENELITIAN}

Jenis penelitian ini tergolong eksperimen semu (quasi experiment), menggunakan desain yaitu "Non-equivalent Control Group Design". Penelitian ini di lakukan di SD Gugus IV Kuta Utara yang terdiri dari 5 SD. Populasi pada penelitian ini terdapat 7 kelas dengan jumlah 209 siswa. Penentuan sempel dalam penelitian ini menggunakan teknik random sampling. Adapun sempel dalam penelitian ini yaitu kelas V SD No 1 Kerobokan Kelod sebagai kelompok eksperimen dan kelas $V^{b}$ SD No 3 Kerobokan Kelod sebagai kelompok control. Data yang dikumpulkan pada penelitian ini yakni data kompetensi pengetahuan IPA siswa.

Pengumpulan data penelitian menggunakan metode tes. Tes yaitu pengukuran yang digambarkan dalam angka, skala maupun sistem kategori mengenai tingkah laku yang bersifat objektif (Yusuf, 2015). Tes yang digunakan pada penelitian ini yakni tes pilihan ganda biasa. Dalam tes pilihan ganda biasanya menyediakan alternative kemungkinan jawaban yaitu a, b, c, ataupun d (Arikunto, 2015). Siswa yang menjawab dengan benar butir tes mendapat skor yakni 1 dan siswa menjawab dengan salah butir tes mendapatkan skor yakni 0 . Tes pilihan ganda disusun sesuai kisi-kisi soal yang memuat KD dan indikator yang mencakup 1) Menjelaskan tentang sifat-sifat benda padat, cair dan gas 2) Menjelaskan perubahan wujud benda mencair, membeku, menguap, menyublim, mengembun, dan mengkristal 3) Menentukan peristiwa perubahan wujud benda mencair, membeku, menguap, menyublim, mengembun, dan mengkristal 4) Mengidentifikasi wujud benda dan peristiwa perubahan wujud benda 5) Membedakan perubahan wujud benda mencair, membeku, menguap, menyublim, mengembun, dan mengkristal 6) Menganalisis peristiwa perubahan wujud benda padat, cair, dan gas 7) Menjelaskan perubahan wujud dan suhu benda yang dipengaruhi oleh kalor atau panas 8) Menganalisis perubahan suhu benda yang dipengaruhi oleh kalor atau panas. Sebelum metode ini digunakn sebagai alat untuk mengumpulkan data terlebih dahulu di lakukan pengujian validitas isi dan butir, uji daya beda, tingkat kesukaran dan reabilitas. Metode analisis data yang dipergunakan dalam penelitian ini yakni GnS yang diperoleh dari hasil Pretest maupun posttest. Setelah data GnS terkumpul langkah selanjutnya adalah melakukan uji Hipotesis dengan mengunakan uji t. sebelum dilakukan uji t terlebih dahulu melakukan uji prasyarat meliputi uji normalitas dan homogenitas.

\section{HASIL DAN PEMBAHASAN}

\section{HASIL}

Berdasarkan tujuan penelitian maka pelaksanaan penelitian dilakukan kepada sampel penelitian yakni kelompok eksperimen kelas V SD No 1 Kerobokan Kelod yang diberikan perlakuan berupa model SETS berbantuan media audio visual dan kelas $\mathrm{V}^{\mathrm{b}}$ SD No 3 Kerobokan Kelod yang menjadi kelas kontrol pembelajaran dilaksanakan secara konvensional. Setiap kelas diberikan 6 kali perlakuan dan setelah itu diberikan post-test guna mendapatkan data skor dari setiap sampelnya. Berdasarkan perhitungan yang dilakukan dideskripsikan data kedua kelompok penelitian dapat disajikan pada tabel 1 . 
Tabel 1. Deskripsi Data Kompetensi Pengetahuan IPA

\begin{tabular}{l|c|c}
\hline \multicolumn{1}{c|}{ Deskripsi Data } & Kelompok Eksperimen & $\begin{array}{c}\text { Kelompok } \\
\text { Kontrol }\end{array}$ \\
\hline $\mathrm{N}$ & 32 & 30 \\
Mean & 0,782 & 0,710 \\
Standar Deviasi & 0,099 & 0,242 \\
Varians & 0,01 & 0,006 \\
Nilai GnS Minimum & 0,65 & 0,61 \\
Nilai GnS Maximum & 1,00 & 0,94 \\
\hline
\end{tabular}

Berdasarkan Tabel 1 didapatkan nilai mean pada kelompok eksperimen adalah 0,782 sedangkan pada kelompok kontrol nilai mean yang didapatkan adalah 0,710 . Hal ini berarti kelompok eksperimen memiliki nilai rata-rata lebih tinggi dibandingkan dengan kelompok kontrol. Uji prasyarat analisis selanjutnya adalah uji normalitas data. Adapun hasil dari uji normalitas data $\mathrm{GnS}$ dapat disajikan pada tabel 2.

Tabel 2. Hasil Uji Normalitas Data GnS

\begin{tabular}{|c|c|c|c|c|}
\hline No & Sampel & $\begin{array}{c}\mid \text { Ft-Fs } \mid \\
\text { maksimum }\end{array}$ & $\begin{array}{c}\text { Nilai tabel } \\
K S\end{array}$ & Keterangan \\
\hline 1 & $\begin{array}{l}\text { Model SETS berbantuan Media } \\
\text { Audio Visual }\end{array}$ & 0,157990 & 0,234 & $\begin{array}{l}\text { Berdistribusi } \\
\text { Normal }\end{array}$ \\
\hline 2 & Pembelajaran Konvensional & 0,120148 & 0,242 & $\begin{array}{l}\text { Berdistribusi } \\
\text { Normal }\end{array}$ \\
\hline
\end{tabular}

Berdasarkan Tabel 02. Diperoleh kelompok eksperimen diperoleh nilai |Ft-Fs| maksimum adalah 0,157990. nilai tersebut kemudian dibandingkan dengan nilai tabel $K S$ yaitu 0,234 . Karena nilai $|\mathrm{Ft}-\mathrm{Fs}|$ maksimum $<$ nilai tabel $K S(0,157990<0,234)$ maka Ho diterima. Ini berarti data berdistribusi normal. Adapun hasil uji homogenitas dapat disajikan pada tabel 03 .

Tabel 03. Hasil Uji Homogenitas Varians Data GnS

\begin{tabular}{llrcrrr}
\hline No & \multicolumn{1}{c}{ Sampel } & $\mathrm{s}^{2}$ & $\mathrm{Dk}$ & $\mathrm{F}_{\text {hit }}$ & $\mathrm{F}_{\text {tab }}$ & Kesimpulan \\
\hline 1 & Model SETS berbantuan & 0,01 & 31 & & & \\
2 & $\begin{array}{l}\text { Media Audio Visual } \\
\text { Pembelajaran }\end{array}$ & 0,006 & 29 & 1,667 & 1,848 & Homogen \\
Konvensional & & & & & \\
\hline
\end{tabular}

Berdasarkan Tabel 03. Diperoleh hasil analisis dimana $F_{\text {hit }}=1,667$, kemudian dibandingkan dengan $F_{\text {tabel }}$ pada df pembilang : $32-1=31$ dan df penyebut : 30-1 = 29 dengan tingkat kesalahan 0,05 , sehingga didapatkan $F_{\text {tab }}$ adalah 1,848, ini berarti $F_{\text {hit }}(1,667)$ $<\mathrm{F}_{\text {tabel }}(1,848)$, maka varians data kompetensi pengetahuan IPA kelompok eksperimen dan kelompok kontrol dinyatakan Homogen.

Setelah dilaksanakannya uji normalitas sebaran data dan uji homogenitas varians dari kedua kelompok yang memperoleh kesimpulan pada uji normalitas data GnS berdistribusi normal, dan pada uji homogenitas Varians Data GnS mempunyai varians yang homogen, 
hal selanjutnya yang dilakukan adalah uji hipotesis. Adapun hasil analisis uji t dapat dapat disajikan pada tabel 4 .

Tabel 04. Hasil Analisis Uji t

\begin{tabular}{|c|c|c|c|c|c|c|c|c|c|}
\hline No & Sampel & & $\mathrm{N}$ & $\mathrm{Dk}$ & $\overline{\bar{X}}$ & $\mathrm{~s}^{2}$ & $\mathrm{t}_{\text {hit }}$ & $\mathrm{t}_{\mathrm{tab}}$ & Ket \\
\hline 1 & $\begin{array}{l}\text { Model } \\
\text { berbantuan }\end{array}$ & $\begin{array}{r}\text { SETS } \\
\text { Media }\end{array}$ & 32 & & 0,782 & 0,01 & & & \\
\hline 2 & $\begin{array}{l}\text { Audio Visual } \\
\text { Pembelajaran } \\
\text { Konvensional }\end{array}$ & & 30 & 60 & 0,710 & 0,006 & 3,1 & 2,0 & $\mathrm{H}_{\mathrm{o}}$ ditolak \\
\hline
\end{tabular}

Berdasarkan tabel 04. Uji hipotesis diperoleh $t_{\text {hit }}=3,154$, dengan menggunakan tingkat kesalahan 0,05 dan $\mathrm{df}=60$ diperoleh nilai $\mathrm{t}_{\mathrm{tab}}=2,000$ sehingga $\mathrm{t}_{\text {hit }}=3,154>\mathrm{t}_{\mathrm{tab}}=$ 2,000. Dengan demikian $\mathrm{H}_{\mathrm{a}}$ diterima. Hal ini berarti terdapat perbedaan yang signifikan kompetensi pengetahuan IPA antara kelompok yang dibelajarkan menggunakan model pembelajaran SETS berbantuan media Audio Visual dengan kelompok yang dibelajarkan menggunakan pembelajaran konvensional pada kelas V SD Gugus IV Kuta Utara Tahun Ajaran 2019/2020.

\section{PEMBAHASAN}

Perbedaan yang signifikan kompetensi pengetahuan IPA disebabkan oleh perlakuan berupa metode pembelajaran SETS berbantuan media Audio Visual yang diterapkan pada kelompok eksperimen, adapun keunggulan model pembelajaran ini menurut Yeni et al., (2020) yaitu 1) Model ini menekankan proses atau bagaimana cara - cara peserta didik mampu memperoleh konsep dalam bidang ilmu terentu, 2) Peserta didik akan memperoleh konsep, fakta, generalisasi dari masing - masing bidang ilmu yang dibelajarkan, 3) Peserta didik akan dituntun untuk selalu bertindak nyata, 4) Menumbuhkan sikap menghargai penemuan orang lain, selalu bersyukur kepada tuhan, 5) Menumbuhkan kreativitas yang mencakup perilaku individu yaitu : (a) Kelancaran, (b) Fleksibelitas, (c) Originalitas, (d) Elaborasi, (e) Sensitivitas, (f) Aplikasi Konsep. Penerapan model pembelajaran SETS berbantuan media Audio Visual pada kelompok eksperimen menjadikan pembelajaran lebih menarik, menyenangkan, dan bermakna sehingga kemampuan kompetensi pengetahuan IPA menjadi lebih baik. Model pembelajaran SETS adalah model pembelajaran yang selalu mengangkat permasalahan yang memiliki konsep - konsep dimana didalamnya terdiri dari unsur sains dan teknologi yang sedang berkembang disekitar kita seperti lingkungan, teknologi dan masyarakat.

Dalam kegiatan pembelajaran dikelas untuk menunjang kelancaran dalam penyampaian suaut materi, guru dapat memadukan model pembelajaran SETS dengan media pembelajaran. Media pembelajaran merupakan suatu komponen pembelajaran yang memiliki kaitan erat dan memiliki peran penting dalam menunjang keberhasilan suatu pembelajaran. Bermacam media pembelajaran dapat dipadukan atau digunakan dalam proses penyampaian materi pada kegiatan pembelajaran namun disesuaikan terhadap materi yang dijelaskan, salah satunya yaitu media pembelajaran audio visual. Media audio visual adalah media perantara yang mengandung komponen suara dan gambar yang dapat dilihat dan didengarkan secara terpadu saat mengkomunikasikan informasi. Sedikit berbeda dengan pembelajaran pada kelompok eksperimen, kegiatan pembelajaran yang 
berlangsung pada kelompok kontrol kurang optimal karena selama proses pembelajaran guru yang lebih aktif dalam penyampaian materi (teacher centered) sehingga siswa kurang aktif dalam partisipasi di kelas Pembelajaran di kelas lebih banyak memberikan ceramah daripada kegiatan yang melibatkan siswa. Kegiatan siswa lebih banyak dilatih untuk membuat dan menjawab soal-soal yang diberikan kemudian mempertanggung jawabkannya sehingga mengakibatkan kompetensi pengetahuan IPA siswa kurang optimal.

Hasil penelitian ini didukung oleh penelitian yang dilaksanakan oleh Ayu Sri Dwi Ariani et al. (2013) yang menyatakan Penerapan model pembelajaran SETS dalam pembelajaran IPA di sekolah dasar lebih efektif karena dapat menciptakan pembelajaran yang lebih realistis dan bermakna, selain itu model pembelajaran SETS dapat berimplikasi meningkatkan hasil belajar siswa hal ini dikarenakan langkah pembelajaran dilakukan dengan pengaktifan atau pengaksesan pengetahuan awal siswa, sehingga mereka mengungkapkan ide-ide atau gagasan-gagasan awal yang dimiliki. Kemudian ditindaklanjuti dengan menyediakan suatu aktivitas kelas, sehingga siswa mendapatkan pengalaman belajar dan mulai membangun konsep-konsep ilmiah. Sependapat juga dengan Winangun (2020) yang menyatakan mengenai model pembelajaran SETS memiliki beberapa keunggulannya tersendir antara lain meningkatkan motivasi belajar siswa karena siswa dilibatkan secara aktif dalam proses pembelajaran kemudian membantu mengembangkan sikap ilmiah siswa serta dalam proses pembelajaran menjadi lebih bermakna. Sejalan juga dengan Sidi \& Mukminan ( 2016) yang menyatakan media audio visual berpengaruh untuk meningkatkan hasil belajar siswa karena tidak hanya bisa mendengarkan penjelasan guru siswa juga dapat melihat secara abstrak. Pendapat lainnya juga oleh Asmara (2015) yang menyatakan media audio visual berpengaruh terhadap prestasi siswa disekolah. Sejalan juga oleh Hayati \& Harianto (2017) yang menyatakan media audio visual dapat meningkatkan minat siswa untuk belajar dan meningkatkan prestasinya dibidang sains.

Adapun implikasi yang didapatkan dalam penemuan-penemuan tersebut menunjukkan bahwa model SETS berbantuan media audio visual berpengaruh pada kompetensi pengetahuan IPA siswa sekolah dasar. Dengan demikian penelitian ini membuktikan bahwa model SETS berbantuan media audio visual baik diterapkan pada saat pembelajaran salah satunya pada muatan pelajaran IPA. Keberhasilan dalam penggunaan model SETS berbantuan media audio visual yaitu pada pembelajaran yang siswa terlibat langsung dengan bantuan suara dan gambar yang nyata sehingga siswa mampu lebih mengeksplorasi pengetahuannya yang tidak sebatas hafalan teori dan tentu siswa akan memahami materi yang dipelajari lebih lama.

\section{SIMPULAN}

Berdasarkan analisis data serta pembahasan maka terdapat perbedaan yang signifikan pada Kompetensi Pengetahuan IPA antara kelompok yang dibelajarkan dengan model pembelajaran SETS berbantuan media audio visual dengan kelompok yang dibelajarkan melalui pembelajaran konvensional pada kelas IV SD. Hal ini dapat disimpulkan bahwa terdapat pengaruh yang signifikan model pembelajaran SETS berbantuan media audio visual sekolah terhadap kompetensi pengetahuan IPA siswa kelas IV SD. Sesuai dengan hasil temuan penelitian ini, untuk guru, kepala sekolah serta peneliti lainnya agar lebih memperkaya diri dengan memiliki banyak pilihan model pembelajaran sehingga nantinya dapat memaksimalkan pencapaian tujuan pembelajaran serta dengan mengaplikasikan 
model SETS berbantuan media audio visual pada proses belajar mengajar IPA sehingga terwujud pembelajaran yang menyenangkan bagi siswa.

\section{DAFTAR PUSTAKA}

Amelia, W. (2019). Pengaruh Metode Pembelajaran dan Kemampuan Berpikir Kritis Terhadap Hasil Belajar IPA (Penelitian Eksperimen Siswa Kelas V SDN 20 Kota Serang Banten). Jurnal Ilmiah Pendidikan Guru SD, 1(1), 109-122.

Anak Agung G, A. (2012). Buku Ajar Metodologi Penelitian Pendidikan (pp. 56-57). Undiksha.

Ansori, I., Jaelani, A. K., \& Affandi L. Hamdian. (2020). Pengaruh Model Contextual Teaching And Learning dengan Media Video Pembelajaran Terhadap Hasil Belajar IPA Siswa Kelas V SDN 9 Ampenan Tahun Pelajaran 2019/2020. 1(1), 33-41.

Aprianingtyas, M., \& Sumadi. (2016). Pengaruh Model Pembelajaran Sets ( Science, Environment , Technology , and Society ) Terhadap Prestasi Belajar Fisika. Jurnal Ilmiah Pendidikan Fisika-COMPTON, 3(2), 1-8.

Ardianti, S. D., Wanabuliandari, S., Rahardjo, S., \& Kudus, U. M. (2019). the Implementation of E-Jas Science Edutainment To Improve Elementary School Student' S Conceptual Understanding. 8(1), 1-6.

Arikunto, S. (2015). Dasar-dasar Evaluasi Pendidikan (pp. 40-44). PT. Bumi Aksara.

Asmara, A. P. (2015). Pengembangan Media Pembelajaran Berbasis Audio Visual Tentang Pembuatan Koloid. Jurnal Ilmiah Didaktika, 15(2), 156.

Ayu Wirati, S. (2014). Pengaruh Model Pembelajaran Science Environment Technology And Society (Sets) Terhadap Sikap Peduli Lingkungan Pada Pembelajaran IPA Siswa Sekolah Dasar Ervin Rudianto 1), Siti Kamsiyati 2), Kuswadi 3) . 449.

Desstya, A. (2018). The 8 th University Research Colloquium 2018 Universitas Muhammadiyah Purwokerto Joyfull Learning In Science ( Pelatihan Percobaan IPA Sederhana di SD Bener I dan Bener II ) The 8 th University Research Colloquium 2018 Universitas Muhammadiyah Purwokerto. 51-56.

Desy Anwar. (1996). Pengaruh Model Pembelajaran Inside Outside Circle Berbantuan Asesmen Fortopolio Terhadap Kompetensi Pengetahuan IPA. IAIN Raden Intan Lampung, 2(1), 9-37.

Devi, P. I. S., Putra, M., \& Putra, D. K. N. S. (2019). Pengaruh Model Pembelajaran Inside Outside Circle Berbantuan Comic Card Terhadap Kompotensi Pengetahuan Ips Kelas V. Media Komunikasi FPIPS, 17(2), 100-109.

Dwi Ariani, S. R., Nugraheni, D., \& Mulyani, S. (2013). Pengaruh Pembelajaran Bervisi Dan Berpendekatan Sets Terhadap Prestasi Belajar Ditinjau Dari Kemampuan Berpikir Kritis Siswa Kelas X Sman 2 Sukoharjo Pada Materi Minyak Bumi Tahun Pelajaran 2011/2012. Jurnal Pendidikan Kimia Universitas Sebelas Maret, 2(3), 3441.

Fatchan, A., Soekamto, H., \& Yuniarti, Y. (2014). Pengaruh Model Pembelajaran Science, 
Environment, Technology, Society (SETS) Terhadap Kemampuan Berkomunikasi Secara Tertulis Berupa Penulisan Karya Ilmiah Bidang Geografi Siswa SMA. Jurnal Pendidikan Dan Pembelajaran (JPP), 21(1), 33-40.

Fujiyanto, A., Jayadinata, A. K., \& Kurnia, D. (2016). Penggunaan Media Audio Visual Untuk Meningkatkan Hasil Belajar Siswa Pada Materi Hubungan Antarmakhluk Hidup. Penggunaan Media Audio Visual Untuk Meningkatkan Hasil Belajar Siswa Pada Materi Hubungan Antarmakhluk Hidup, 1(1), 841-850.

Hayati, N., \& Harianto, F. (2017). Hubungan Penggunaan Media Pembelajaran Audio Visual dengan Minat Peserta Didik pada Pembelajaran Pendidikan Agama Islam di SMAN 1 Bangkinang Kota. Al-Hikmah: Jurnal Agama Dan Ilmu Pengetahuan, 14(2), 160-180.

Irwandi. (2019). Penggunaan Media Audio Visual dalam Peningkatan Hasil Belajar IPA. Journal of Chemical Information and Modeling, 53(9), 1689-1699.

Kosasih, E. (2016). Strategi Belajar dan Pembelajaran Implementasi Kurikulum 2013 (pp. 79-81). Yrama Yadnya.

Laka, B. M. (2017). Jurnal Pedagogika dan Dinamika Pendidikan. Jurnal Pedagogika Dan Dinamika Pendidikan, 6(1), 1-11.

Mahdalena, S \& Sain, M. (2018). Pendidikan 2 SMA Biologi FKIP Universitas Sebelas Maret Muhammadiyah 1 Karanganyar. 5, 83-96.

Nursa'adah, F. P. (2015). Pengaruh Metode Pembelajaran dan Sikap Siswa pada Pelajaran IPA Terhadap Hasil Belajar IPA. Formatif: Jurnal Ilmiah Pendidikan MIPA, 4(2), $112-123$.

Purwanto, H \& Aminah, S. (2020). Pengaruh Model Contextual Teaching and Learning Terhadap IPA. 7(1), 1-5.

Rini, C. P. (2017). Pengaruh Pendekatan Sets (Science, Environment, Technology and Society) Terhadap Keterampilan Proses Sains Siswa Sekolah Dasar. Pendas : Jurnal Ilmiah Pendidikan Dasar, 2(1), 56.

Sabardila, A., Fachri, A. R., Santoso, E., Aini, N. N., Safitri, M., Putri, D. M., Damayanti, N. A., Hermawati, L., Pratiwi, A. N., \& Safira, R. (2020). Peningkatan Antusiasme dan Pemahaman Siswa dalam PBM melalui Metode Talking Stick di MIM Jatisari Kedungdowo, Boyolali. Buletin KKN Pendidikan, 1(2), 56-62.

Samatowa, A. (2016). Pembelajaran IPA SD (pp. 67-68). PT. Indeks.

Sary, L. L., Djumhana, N., \& Hendriani, A. (2020). Pengaruh Pembelajaran Sets Terhadap Keterampilan Proses Sains Siswa Kelas V Sekolah Dasar. Jurnal Pendidikan Guru Sekolah Dasar, 4(3), 194-207.

Sidi, J., \& Mukminan, M. (2016). Penggunaan Media Audiovisual untuk Meningkatkan Hasil belajar IPS di SMP. Socia: Jurnal Ilmu-Ilmu Sosial, 13(1), 53-72.

Subawa, P. (2018). Mencetak Lulusan Yang Berkarakter dan Berkualitas. Purwadita, 2(1), 87-93. 
Susanto, A. (2013). Teori Belajar dan Pembelajaran di Sekolah Dasar (pp. 99-101). Prenada Media Grup.

Winangun, I. M. A. (2020). Media Berbasis Budaya Lokal dalam Pembelajaran IPA SD. $1(1), 65-72$.

WIsudawati, I. \& E. (2017). Penggunaan Media Audio Visual Terhadap Ketuntasanbelajar Ips Materi Perkembangan Teknologi Produksi, Komunikasi, Dan Transportasi Pada Siswa Kelas Iv Sd Negeri 20 Banda Aceh. Jurnal Pesona Dasar, 3(4), 22-33.

Yamin, M.R., \& K. (2020). Analisis Kebutuhan dan Pengembangan Media Pembelajaran IPA. 4, 105-114.

Yeni, A., Wote, V., \& Radja, A. (2020). Pengaruh Bahan Ajar Berpendekatan SETS Society ) terhadap Hasil Belajar Sains Kompetensi Peristiwa Alam di Indonesia. 17.

Yuniastuti, E. (2015). Pengaruh Model Pembelajaran SETS (Science, Environment, Technology and Society) Terhadap Hasil Belajar Biologi Siswa Kelas VII SMP Kartika V-1 Balikpapan Tahun Pelajaran 2015/2016. JST (Jurnal Sains Terapan), $1(2), 72-78$.

Yusuf, M. (2015). Asesmen dan Evaluasi Pendidikan Pilar Penyedia Informasi dan kegiatan Pengendalian Mutu (pp. 22-25). Prenada Media Grup. 